Portland State University

PDXScholar

\title{
Behavioral Changes Due to Overpopulation in Mice
}

James Robert Hammock

Portland State University

Follow this and additional works at: https://pdxscholar.library.pdx.edu/open_access_etds

Part of the Applied Behavior Analysis Commons, Experimental Analysis of Behavior Commons, and the Other Animal Sciences Commons

Let us know how access to this document benefits you.

\section{Recommended Citation}

Hammock, James Robert, "Behavioral Changes Due to Overpopulation in Mice" (1971). Dissertations and Theses. Paper 1429.

https://doi.org/10.15760/etd.1428

This Thesis is brought to you for free and open access. It has been accepted for inclusion in Dissertations and Theses by an authorized administrator of PDXScholar. Please contact us if we can make this document more accessible: pdxscholar@pdx.edu. 
AN ABSTRACT OF THE THESIS OF James Robert Hammock for the Master of Science in Psychology presented July 26, 1971.

Title: Behavioral Changes Due to Overpopulation in Mice.

APPROVED BY MEMBERS OF THE THESIS COMMITTEE:

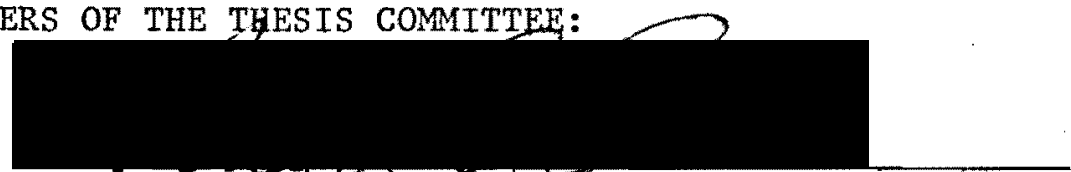

Rónald E. Smith, Chairman

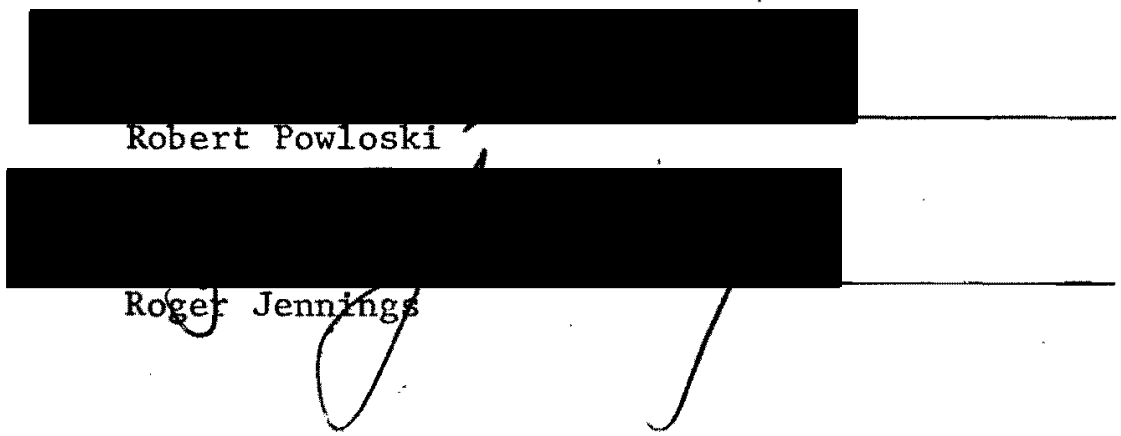

Previous research has found that if a population were allowed to exceed a comfortable density level, then many catastrophic events occurred such as increased mortality among the young, cannibalism, homosexuality, and lack of maternal functions. The most influential researcher in this area is Calhoun (1962), after whose experimental design a pilot study was fashioned to replicate his results. The results of this pilot study inspired a more detailed research project of which this thesis is an account.

Forty-eight albino mice of the Swiss Webster strain were divided Into three groups of sixteen each. Each group consisted of ten females and six males chosen randomly; two groups were to serve as experimental groups and the other group as the control. The experimenta1 groups were placed into apparatus $155 / 8^{\prime \prime} \times 201 / 2^{\prime \prime} \times 8^{\prime \prime}$ and 
the control group in an apparatus $477 / 8^{\prime \prime} \times 611 / 2^{\prime \prime} \times 8^{\prime \prime}$. The three groups were allowed to multiply freely with nesting material, food and water provided proportionately as their numbers grew. The experimental groups were allowed to overpopulate while the control group was not.

There were six behavior variables noted as the experiment proceeded: (1) grooming, (2) homosexuality, (3) nest building, (4) retrieving of young, (5) fighting, and (6) mortality of the young. It was predicted that grooming, nest building, and retrieving of the young would decrease in frequency as the population increased, while fighting, homosexuality and mortality of the young would increase with the rising population density. The experiment was conducted for six months and fourteen days.

The result of this experiment was a total lack of overpopulation. The two experimental groups never weaned any pups though they produced many, and the control group grew to the comfortable limits of its apparatus and then ceased weaning any further pups. In an effort to ascertain the reasons for these results, one-of -the experimental groups was artificially reduced in number; whereupon it promptly weaned forty-one percent of its first litter, thirty percent of its second, and none of its third. At the time of its first weaning, this group was technically overpopulated.

In corclusion an hypothesis is propcied to explain the results. It is felt that each population has an innate knowledge of its comfortable limits with regard to density and will maintain this crucial density level if necessary. The group's ability to control its popula- 
tion is directly related to a time factor in that if a population were allowed to approach its crucial density level gradually it would not exceed it; however if there were little or no approach time, then this level would be exceeded. 
BEHAVIORAL CHANGES DUE TO OVERPOPULATION IN MICE

by

JAMES ROBERT HAMMOCK

A thesis submitted in partial fulfillment of the requirements for the degree of

MASTER OF SCIENCE

in

PSYCHOLOGY

Portland State University

1971 
TO THE OFFICE OF GRADUATE STUDIES:

The members of the Committee approve the thesis of

James Robert Hammock presented July 26, 1971.

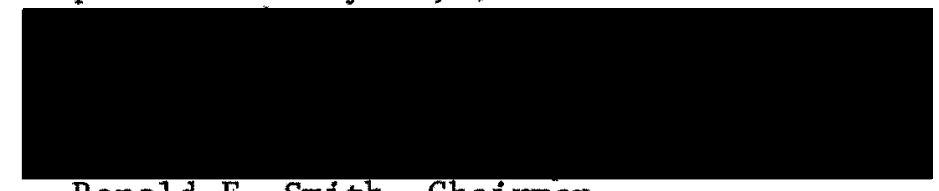

Ronald E. Smith, Chairman

Robert Powloski

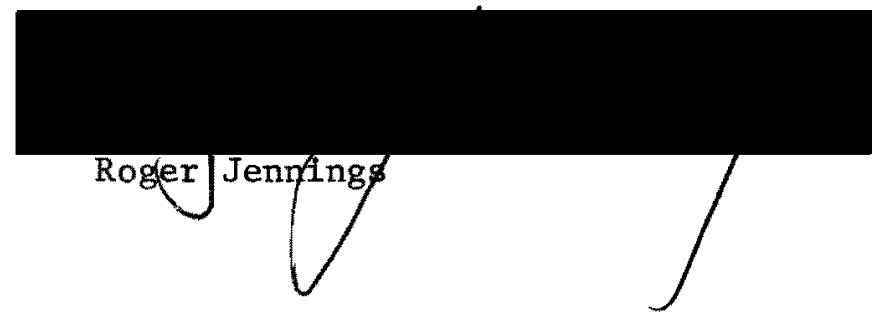

APPROVED :

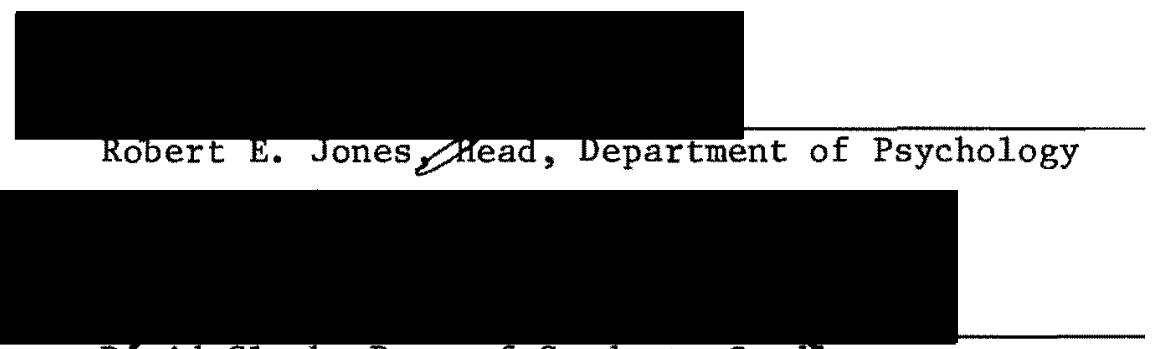

Dávid Clark, Dean of Graduate Studies

Ju1y 26, 1971 


\section{ACKNUWLEDGEMENTS}

I wish to express apprectation to my combictee members-IIx. Roneld Smith, Dr. Fobert Powloski, and Dr. Horzce Manntnowithout whom this thesis could not have been written. As chairmain of my thesis committee, Dr. Smith has spent many hours helping ine and listening to the almost endless trials and tribulations of thy research. His help and inspiration shall not be rorgotten. Like Dr. Smith, Dr. Powloski has spent many hours helping me and his contribution to the resulting theory gives it any value it might possess. He was always present when needed and served as a calming influence when I became excited which was often. A special thank you goes to $\mathrm{Dr}$. Manning who willingly replaced another comittee member whan needed. His expertise with measurement techniques was most useful in determining the proper procedures for analyzing the data of this thesis. Finally a note of gratitude goes to my wife whose unequaled mastery of English gramar and spelling made this thesis readable. 
TABLE OF CONTENTS

PAGE

ACKNOWLEGEMENTS . . . . . . . . . . . . . . . 111

LISI OF FIGURES . . . . . . . . . . . . . . . . . v v

CHAPTER

I REVIEW OF THE LITERATURE . . . . . . . . . . . 1

II PROCEDURE . . . . . . . . . . . . . . . 16

Methods-Part I................ 16

Methods-Part II . . . . . . . . . 19

III RESULTS ..................... 23

IV DISCUSSION .................. 35

General ................ 35

Future Research ............... 43

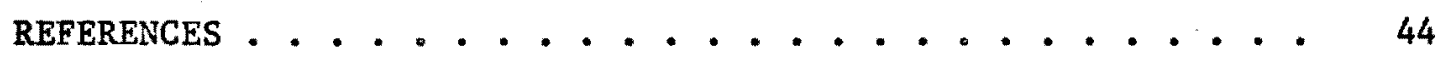




\section{LIST OF FIGURES}

FIGURES

PAGE

I Apparatis for Control Group ........... 20

II Mortality rate for the three population groups . . 24

III Survival rate for experimental group two after artificial population reduction . . . . . . 27

IV Frequency in retrieval of the young for all

three groups . . . . . . . . . . . 30

v Fighting behavior for all groups . . . . . . . 32 


\section{CLAPTER I}

\section{REVIEW OF THE I.ITERATURE}

The concern with populations-- their growth, demise, mrvements: and effects upon the behavior of the individual-- has been the topic of much speculation and little scientific research. The term population has been defined as any contiguousiy distributed grouning ot a single species which is characterized by both genetic and cuitural continuity through several generations (Calhoun, 1952). This population at a given time is the result of the interaction of three generaal forces: (1) reproduction which increases the population, (2) mortality which decreases the population, and (3) movement which either increases or decreases the population depending upon the net result of inmigration or emigration (Davis, 1953). The primary concern of most population research has been the growth of populations by either reproduction or immigration. Pearl (1927) suggested that population growth followed a "logistic curve". This curve was explained by Strecker (1955): the population tends to multiply according to a growth curve which rises slowly at first and then picks up momentum until it shoots upward almost verticaliy. Pearl feit that as the population grew, as represented by the logistic curve, it would begin to stabllize at some asymptotic level that could be determined mathematically. Using his mathematical formulation, Pear1 (1930) determined the asymptotic population level for the United States was 197.27 million. He fielt this nutber would never or should never be reacined although it would be close by the year 2100 . If there has 
been a serious or cataclysmic alteration of the conditions under which the earlier growth of the population took place then a popula. tion will not follow this logistic curve (Pear1 \& Reed, 1930). Pearl (1930) defined these conditions as climatic, geological, biological, economic, and social. It is interesting that he does not include ecology as one of his conditions; however with his list of conditions, he can explain any deviation in the population growth. For oxample, the national depression of the $1930^{\prime}$ s would have an effect on tie population growth. Unfortunately he does not specifically state the effects of these conditions on a population's growth pattern. Pear1 (1927) determined that the rate of population growth included the following: (1) a population grows according to the same mathematical laws that Individuals follow in the growth of their bodies, (2) a human population grows according to the same laws as does an experimental population of lower animals, and (3) the rate of fertility of a population is negatively correlated with the density of this population. Woolston (1929) argued against these assumptions and the logistic curve. He stated that all populations do not either increase or remain stationary; nor when they do grow, do they always follow the logistic curve. Woolston would seem to be justified in his criticism of Pearl's (1927, 1930) logistic curve theory for the population of the United States, as of 1970 , is approaching 210 million. However, the assumpticn that a human population grows according to the same laws as does an experimental population of lower animals has inspired many experimenters to use lower anjmal populations to study the effects of overpopulation. 
The effacts of overpopulation on behavior have been dramatic. Pear1 (1932) studied the effects of overpopulation or egg piuduction In Drosophila Melanogaster (fruit fly). He found that as the density of population within a limited, closed universe (a bottle) increased, the rate of egg production per female decreased. This decrease was considered an indication of a change in physiclogical equilibrium resuling in part from collisions. The effects of increased population also showed itself in an alteration in food intake and energy out-put In muscular work. If the flies were switched from a high density group to a low density group, the rate of egg production was higher In the low group and lower in the high group. This study supports the third assumption of growth rate, that the rate of fertility is negatively correlated with population density. Pearl's (1932) study was later supported by Maclagan and Dunn (1934).

The most comprehensive work on animal overpopulation and resultant behavioral changes was done by Calhoun (1962). In his study, Calhoun used Norway rats of the albino strain and divided them into six different populations. Each population was allowed to increase to approximately "twice the number that could occupy the available space". He determined this number based on his own past experience with rat populations. The experiment was conducted in two series; in the first series thirty-two rats were used and in the second series, fifty-six. The number was divided equally between males and fenales. The apparatus used was ten feet by fourteen feet. Calhoun observed eaci population carefully for sixteen months. The pathology of overpopulation was most apparent in the females. They were unable to 
carry their litters to full term or survive deiivery of their 1itters, if they did give birth. Christian (1956) found there was a thirtyone percent decline in the number of normal embryos per mature female in his experimental population, when a11 experimental inice were considered as one group and all controls as another. In a later study, Christian and Lemunyan (1958) found that the number of young per 1itter was significantly less in the crowded females. They concluded that crowding resulted in intra-uterine mortality and probably in diminished fertility, explaining why none of the mice in their seven populations ever appeared pregnant during crowding and why almost half never bore litters, even after segregation.

Calhoun (1962) found most of the females, if they gave birth, neglected their maternal functions, which resulted in their litters dying. The females were less adept at nest building and eventually quit building nests at all. Brown (1953) states that the survival of the litters is a direct result of the type of nest building activity occurring prior to birth. As his population increased, the females could not or would not, build and defend adequate nests. The decrease In nest building was sixty-eight percent. Those with inadequate nests did not have a successiul litter while those with adequate nests did. He concluded that the isolation of the female and her nest from the activities of other mice is important in the successful weaning of the litters born. The partial or complete breakdown of nest defense appears one of the key factors in the destruction of subsequent litters and hence population control. This inability in nest construction and defense was also noted by Strecker (1955). 
Southwick (1955) explained another variable in his discussion of nest destruction and the females' inability to coustruct nests. He found that the intermingling of sexes at the nest site apparently influences litter survival. The presence of one or more adult males in a nest box had a detrimental effect on survival of the pups. In an experimental group of 107 1itters, survival with one or more adult males attending was between nineteen and thirty-one percent, whereas survival of 129 litters, attended by females alone or in groups, averaged fifty-nine percent. The number of adult males in attendance with a litter made little difference to its survival; the presence of one male was as harmful as the presence of several. Southwick also found that the type of nest constructed, if there was one, played a role in the survival rate of the litters. If there were no nests constructed, there were no survivors. A bow1 shape nest resulted in a sixty to ninety percent survival rate. A platform nest resulted in a fiftynine percent survival rate and a platform nest with two or more adults resulted in an eighteen percent survival rate. The females in Calhoun's study (1962) discontinued transporting their pups from one place to another. The young were left or dropped and not retrieved which in turn resulted in their deaths. Southwick also found desertion of the young a major contributor in population control.

Is the death rate of adults more prevalent in an overpopulated environment? When examined experimentally, this question has produced mixed results. Calhoun (1962) found the females died readily from disorders in pregnancy and parturition; however, this condition has not been found universally in studies of overpopulation. Southwick found 
that the mortality rates of weaned sub-adults increased significantly after the population had reached its peak, while the mortality rates of adults was largely unaffected.

The inability of females to nourish their young has also been cited as a contributor to population control. This upsetting of maternal physiology was noted by Christian and Lemunyan (1958). They reported that suppressed growth of progeny nurtured by mothers crowded for at least two generations was due to quantitative and/or qualitative deficient lactation. This effect of overpopulation may explain the long continued decline in natural populations following peak levels and a sharp decrease in total numbers. In conclusion, Calhoun (1949) noted that the upsetting of maternal physiology might be one of the limiting factors in population growth.

Calhoun (1962) found the nales to be hypersexual, sexually deviant and hyperactive in an overpopulated environment. The saxual deviancy exhibited itself in the forn of homosexuality. Homosexuality is not uncommon in normal animal populations; however, Calhoun found this behavior in excess of what he had expected. Most of the homosexuals seemed unable to distinguish a sex object and would attack males, females, and juveniles. The males also exhibited a frenetic over-activity Ievel. This high activity level due to overpopulation was also noted by Southwick (1955). A review of the literature suggests that in any overpopulated environment there is an increase in activity and a decrease in fear generally. These conditions depend on the number of individuals present. Davitz and Mason (1955) found that the presence of one rat tended to reduce the strength of a fear re- 
sponse exhibited by another rat. This reduction of fear response has also been reported by Masserman (1943) and Liddell (1950).

In an attempt to explain this heightened astivity. level as found by Calhoun (1952), Morrison and Thatcher (1969) compared the body weight and adrenal weight in albino rats in different size groups. The group sizes were one, four, sizteen, and thirty-two rats. On1y minimal differences were obtained between subjects housed one and four per cage. The major effect of the density variable was seen between these two conditions on the subjects housed sixteen and thirty-two per cage. Group differences in corrected adrenal weights, as measured by analysis of variance across the four population groups, indicated that adrenal weight increases with increased population density. An earlier study by Bronson and Eleftheriou (1963) also found an increase in adrenal weight as population density increased.

Calhoun (1962) found some males displayed a pathological withdrawal syndrome, in which they would eat and drink only when others of the community were asleep. Some became passive to the point of being somambulistic. Even females in estrus were not approached by these males. A good portion of the nales went berserk, attacking females, juveniles and less active males, and even biting others on the tail. This tail-biting is very abnormal behavior for a rodent (Calhoun, 1962).

When the population became large, Calhoun (1962) found that the males began to struggle for status. This struggle manifested itself In a great deal of fighting. Brown (1953) found a definite social hierarchy among house mice caged together. This hierarchy was deter- 
mined and maintained to a considerable degree of fighting. In all cages observed, there appeared to be a social hierarchy set up in which one male was dominant over all other males. Not only males but also females seem to form a hierarchical status. Christian (1961) who found that reproduction by female mice declines with increased population size, also found that the dominant females in a group do most. of the reproducing. In an earlier study, Scott and Fredericson (19bi) found that overpopulation tended to increase the probability of fighting; however, overpopulation did allow for better escape by defeated mice. These results had been observed by Calhoun (1949) and Strecker (1955). When the dominant male had been determined, he immediately established a territorial dominance and claimed many females in his harem. The dominant males would often submit to homosexual advances of subordinate males. Fighting among the subordinate males was common (Calhoun, 1949, 1962). Archer (1970) found that the occurrence of aggressive behavior was correlated with a higher adrenocortical function in overpopulated groups than in isolates.

When is a mouse or rat actually fighting and not engaged in a similarly appearing activity? Investigation, grooming, and sexual behavior are three forms of behavior often confused with fighting. Scott and Fredericson (1951), realizing the difficulty, studied fightIng behavior in rats and mice and devised a system for determining fighting behavior. They divided fighting into four stages: (1) preliminary behavior, (2) attacking behavior, (3) defensive and escape behavior, and (4) noncompetitive fighting. The preliminary behavior consists of hair-fluffing, tail-rattling, and mincing. In hair- 
fluffing, the hair literally stands on end over most of the body, with no exphasis on particular regions as with the cat and dog. One problem is that a poorly groomed animal may give somewhat the same appearance. This becomes a problem in overpopulated environments because the animals in this culture tend not to groom themselves. In tailrattling, the mouse rapidly twitches its tail from side to side so that it takes on a wavy appearance. Mincing occurs when mace are fighting in round-robin fashion. Beeman and Alee (1945) define roundrobin fighting as each mouse meeting every other mouse. Before attacking, the mouse circles around or near the opponent with his body humped up and takes short, rapid steps. In the attacking stage, the behavior takes on two forms; either two mice attack each other or one mouse attacks while the other runs away. When the mice attack, they will bite, scratch, and wrestle. The third stage, defense and escape behavior, begins at the end of the attack stage. When a mouse is beaten, it squeaks when attacked, and if the space allows, will run away. If no escape is possible, the mouse will rear up on its hind feet, holding out the front paws toward the aggressor and remain motionless until attacked, when it may squeak and jump. The ahove behavior is known as "submissive reaction". The final stage, noncompetitive fighting, seems to serve no particular purpose. Calhoun (1950) suggests that this form of fighting is for undisturbed possession of living space. Noncompetitive fighting should become frequent as the population density increases and the available living space decreases.

The final consideration in Calhoun's study (1962) was the change in the area of social behavior with the population as a whole. As the 
population grew, it divided itself into several groups, in each of which the sex-iatios were drastically modified. One group consisted of six or seven females and one male, while another group might con." sist of twenty males and ten fenales. The subjects would congregate in one area to eat rather than eat alone. Eating and other biological activities were transformed into social events in which the principal satisfaction was interaction with oiher rats. Because of the communal activities such as eating and drinking, the animals tended to live in this same general area even with space available elsewhere. Calhoun called this a "behavioral sink". It was hypothesized this togetherness caused a rise in the mortality rate of the young because of neglect. The young that died were usually eaten by the adults. Brown (1953) states that in overpopulated groups partial or complete destruction of the 1itters occurred after parturition. This was caused either by killing or abandoning them. Southwick (1955) found the major mechanism of population limitation was excessive litter nortality due to cannibalism and desertion. Calhoun (1962) observed that the estrous females found themselves pursued by packs of males violating all rules of the ritual mating behavior of their species. He hypothesized that, in time, failures of reproduction combined with mortalIty of the young would cause the colonies to die out completel.y. To test this hypothesis, Calhoun removed eight healthy rats (four of each sex) from his experiment. The rats were six months old. These rats produced fewer litters in the next six months than expected and none of their offspring survived to reach maturity.

Calhoun (1962) never suggests any reasons for his colonies' 
extinction. At this point one might sjeculate as to sume possible causes for this extinction phenomenon. As stated earlier, migration Is a key factor in population growth; and in Calhoun's experinent this was not allowed. Crowcroft and Rowe (1958) found that reproduction recovered after it had been inhibited completely, when migration was permitted. They concluded that such densities, and therefore total inhibition of reproduction, rould not occur in ratural pepulations. Christian (1961) states thet if inigration is permitted from a population when it reaches levels wich would completely suppress reproduction, then reproduction continues rather than being totally inhibited. D'Aulaire and D'Aulaire (1970) found that lemming populations recovered from overpopulation when mass migration occurred. These experiInents limit the significance of Calhoun's results if one wishes to generalize to human populations; however, not all findings agree with the findings of Crowsroft and Rowe, Christian, and D'Aulaire and D'Aulaire. Kalela (1957) and Evans (1949) cite examples of extreme densities obtained by house mice in the wild; these populations exhibited suppression of reproduction. They also found the possibilities for emigration became restricted. One might assume from these studies that if migration was curtailed in the wild, as it was in Calhoun's study, extinction of the population could occur.

Another possible cause for the extinction of Calhoun's populations was a lack of gonadotropic activity. Deevey (1960) found that overpopulation disturbed the entire pituitary-adrenal system and diverted or suppressed the hormones governing sexuality and parental care. Thiessen (1964) found that gonadotropic activity was antagonized 
and reproductive capacities failed when a population becomes over-: populated. He also found that in super-saturated populations, as was Calhoun's, the intensity of these effects was maximized-- social confilct was widespread, hormonal aberration greatest and mortality extensive. This lack of reproduction by females has also been found by Retzlaff (1938), Brown (1953), and Christian (1961). The combination of this lack of reproduction and a high mortality rate of young could very well lead to extinction.

In a recent study, Gandelman (1971) found that removal of the olfactory bulbs eliminated maternal behavior in lactating and virgin mice and in most instances initiated cannibalism. He felt that olfactory cues emitted by the young stimulate the area of the lateral hypothalamus involved in the expression of maternal behavior. He concluded that without such stimulation, maternal benavior might not be elicited. This study predicted that destruction of the lateral hypothalamus could cause a cessation of maternal behavior. One might assume that in super-saturated environments like Calhoun's (1962) the lateral hypothalamus would be affected resulting in a lack of materna? Instincts and if this affect were permanent it would explain the extinction of Calhoun's population.

In a pilot study (1969), this author followed Calhoun's (1962) study design to determine if his findings could be replicated. Sixteen adult albino mice (eight males and eight females) of the Swiss Webster strain were placed in a confined enclosure and allowed to reproduce freely. The subjects were provided food and water proportionately as their numbers grew. Strecker and Emlen (1953) found 
when food shortage was tested in reference to population growth, the discontinuance of population growth was due to a cessation of reproduction and did not involve any increase in mortality rate of adults or of young born before the food crists. The behavioral changes of both Individuals and the group were of primary importance and each was observed twice daily as the population grew. The population was permitted to increase to approximately four times the number that could occupy the available space comfortably.

The results of this pilot study were similar to those fourd by Calhoun (1962). The lack of maternal care combined with inefficient nest construction and poor defense resulted in a high mortality rate among the second litter (71\%), while the mortality rate for the first 1itter was only two percent. The young that died were eaten by the adults. Nest building by the females was abandoned entirely with the second litter. Retrieving and transporting of the young by the females also ceased by the second litter. Homosexuality increased greatly among the males after the second litter, while normal sexual behavior decreased; the males would attack juveniles as well as other adults. As the population grew, an increase in fighting among the males was noted. The fighting seemed more vicious and each fight lasted for a longer period of time. As the population grew, a frenetic overactivity level was noted among all subjects. This frenetic behavior ceased only when the subjects slept. The individuals within the group would endeavor to isolate themselves from the others. In trying to isolate themselves, the subjects would spend a great deal of time chewing at the wire covering of the apparatus. Some spent as long as thirty 
minutes continuously engaged in this single activity. Any estrous females were pursued by a pack, consisting of three to five males all trying to mount simultaneously. The total number of births per female decreased as the population grew. For example, the first litter consisted of sixty-three while the second litter was only thirty-five, although there were more productive fernales. The subjects would ilie in any available space, with their eyes open, completely igncring all others even though they were walked and defecated upon. Finally, it was noted that complete grooming all but ended. The subjects would clean their faces but not the rest of their bodies. This resulted in a matted unkempt appearance for the total population.

Some of Calhoun's findings were not observed in the pilot study. He found that many females did not survive delivery of their litters. While one female in the pilot study did die shortly after giving birth, her death alone was not significant. This finding agrees with Southwick (1955).

Males alone displayed a pathological withdrawal syrdrome in Calhoun's study while the entire population of this pilot study demonstrated this behavior. One possible cause for this difference wight be in the total size of the two populations. Calhoun's populations were allowed to expand to only twice the number for the available space, while this author's population was four times larger than the space available. The pilot study population was more super-saturated than wos Calhoun's. Being a more super-saturated population, any behavior ehange might be manifested by all the inhabitants, not merely a few. Calhoun found tail biting occurred as his populations grew, while 
this mannerism was not found in the pilot study. This could have been caused by Calhoun's use of rats while this pilot study employed mice, although according to him the choice of rodent should not matter when considering this behavior. In the pilot study, there was no struggle for status among males nor any establishment of territorial dominance, harems, or a "behavioral sink". Calhoun found that as the population grew it divided itself into several groups in which the sex ratios were drastically modified. This did not occur in the pilot study; again the species difference in subjects used could account for these discrepencies. While the population of the pilot study did not die out as Calhoun hypothesized, there was a drastic decrease in the number of young from the first litter $(\mathrm{N}=63)$ to the second $(\mathrm{N}=35)$, and it might be assumed that given a longer period of time, this population might also have become extinct. 


\section{CHAPCER II}

\section{PROCEDURE}

\section{METHODS--PART I}

of the many possible behavior variables that can be affected by overpopulation, six were chosen to be examined by this experimenter. This choice was based on past research of overpopulation and on earlier pilot study. The six behavioral changes examined were: (1) grooming, (2) homosexuality, (3) nest building, (4) retrieving of young, (5) Fighting, and (6) mortality of the young. For each of these variables, the experimental groups were compared with the control group and with each other for any change due to overpopulation.

\section{Grooming}

Grooming was defined as the cleaning and caring of the entire body by the subject. It was assumed that as the population within the experimental groups increased beyond the crucial density level, the ratio of unkempt mice would exceed the ratio found within the control group. The ratio was defined as the number of unkempt mice observed once a week divided by the total number in the population for that week.

\section{Homosexuality}

Homosexuality was defined as any attempted mounting, mounting, or Intromission by 1ike sexes; a frequency count of the number of such occurrences per group compared with the total number within that group was made. It was prericted that as the population density increased 
homosexual activity in the experimental groups would be greater than In the control group.

\section{Nest building}

Nest building included construction and defense of a nest. The observations were made on a "yes-no" basis for each litter, either the females built nests or they did not. The hypothesis was that as the population density increased within the experimental groups, nest building and defense would decrease until eventually no nests would be constructed. It was hypothesized that there should be no change in nest building or defense within the control group.

\section{Retrieving of young}

Any pup that was moved from one position to another was considered retrieved. By broadly defining this variable, any personal attention received by a pup could be recorded; therefore besides measuring just the return of a dropped pup, it also measured personal attention given the pups by the adults. As the population would exceed asymptote, there should be proportionately fewer retrievals in the experimental groups than in the control group. The ratio was determined by dividing the number of retrievals observed by the total number of pups at the time of observation (number of retrievals/number of pups).

\section{Fighzing}

Fighting was distinguished from similar appearing behavior by using the Scott and Fredericson system (1951). The proportion of fights observed within the experimental groups was predicted to exceed those in the control group as the population density increased. Here 
the ratio was the total number of fights per weel, based upon a predetermined schedule of observations, divided by the total population for that observed period (number of fights per werk/total population).

\section{Mortality of the young}

The mortality of the young was defined as the death of any pup for any reason before it was weaned. The normal weaning period for a mouse is twenty-one days (Gandelman, 1971). The survival rate of pups was expected to decrease rapidly once the experimental populations exceeded their asymptotic level, while no significant decrease in the survival rate was anticipated in the control group. The survival rate was calculated as the number of pups alive divided by the number of pups born (number of live pups/number of births).

\section{Observation schedule}

The observation schedule for each of the six behavioral changes was as follows: grooming was observed week1y, the frequency of homosexual activity and the number of fights was recorded for one-quarter hour three times per week for each group, nest building was recorded daily by observing the total number of nests per group, retrieving was observed for one-quarter hour four times per week for each group as pups were available, and mortality of the young was recorded daily when pups were available. All observations were made at random times during the week to avoid any possible effects of a fixed schedule. Before each observation period, there was a fifteen minute delay from the time the observer entered the room until he began recording. This allowed the subjects time to become accustomed to the presence of the 
experimenter.

To aid in the insurance of as litile experinienter bias as possible, a trained observer was employed at five difierent points throughout the experiment to make independent observations with the primary experimenter; and an interrater reliability coefficient was calcuiated. Each variable was tested except for mortality of the young which was obvious and needed no reliability check. For each varjable tested, the resulting Pearson $r=1.00$.

\section{METHODS--PART II}

The subjects were adult albino mice of the Swiss Webster strain. A total of forty-eight mice were used, eighteen males and thirty females. The purpose of having more females than males was to increase the population more rapidly than would occur with an even number of subjects. Mice were chosen primarily because of their smail size and the limited amount of laboratory space available. To insure the fastest population growth, the Swiss Webster strain was chosen because of its breeding capability.

There were a total of three apparatus used varying primarily in their dimensions. Two of the apparatus measured $155 / 8^{\prime \prime} \times 201 / 2^{\prime \prime} \times$ $8^{\prime \prime}$ and one apparatus measured $477 / 8^{\prime \prime} \times 611 / 2^{\prime \prime} \times 8^{\prime \prime}$. Because of the sanitation problem, each small apparatus was equipped with a wire screen floor having a removable tray just beneath it. In the case of the large apparatus instead of a tray, paper was used to accumulate the waste. The wire mesh floors were constructed of $1 / 4^{\text {" hardware }}$ cloth, which was sufficiently small to prevent the pups from falling 
through whlle large enough for defecated material to pass onto the paper below. The two smaller apparatuses were each equipped with a food bin made of $1 / 2^{\prime \prime}$ hardware cloth and two water bottles, while the large apparatus had a similar food bin but three water bottles. The layout of the living area for each apparatus was essentially identical. Along the walls of the rectangular structure there were small cubje? es or "apartments". The cubicles allowed the animals a place in which to build their nests, raise their young, or find solitude. The centrai portion of the apparatus was open-- much like a courtyard-- with food

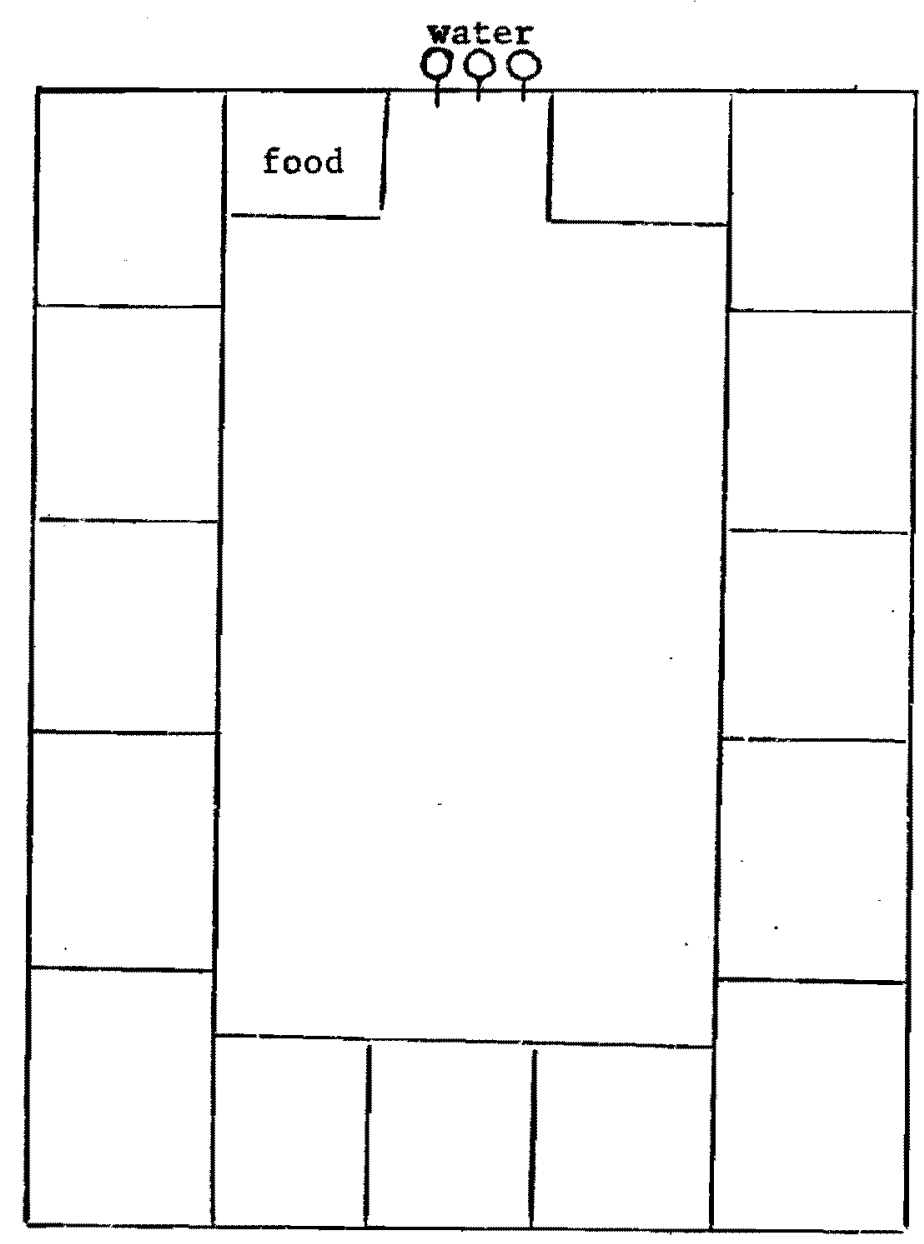

Figure 1. Apparatus for control group 
and water supplied at one end. Figure 1 illustrates the larger apparatus. To insure adequate nesting naterial, strips of paper were provided as needed and removed when soiled. The top of each apparatus was covered in $1 / 2^{\prime \prime}$ hardware cloth which allowed the removal of soiled paper and dead pups. This removal was accomplished with the use of a "grab all" tool which was inserted through the top, and pulled back without the need of removing the attached top each time. Any adult animals that died were removed by detaching one corner of the wire top and pulling the animal out with the "grab all" tool.

From the previous pilot study, it was found that the asymptotic level for the population was approximately fifteen square inches per mouse. This figure was used in establishing each experimental group in this study. Upon arrival, the mice were separated into three groups; each group consisted of six males and ten females. No attempt was made to mark each mouse separately upon his arrival, because of the eventual number of mice anticipated and the impossibility of marking each one. The ability to distinguish males from females was easily accomplished because the genital region on the males was quite visible. One group was placed in each of the two small apparatus to serve as an experimental group. The density level in each of these groups was approximately eighteen square inches per mouse which approximated asymptotic level. By placing of these groups so near asymptotic level, an overpopulated condition would result with the weaning of the first 1itter. The remaining group was placed in the large apparatus to serve as the control group. Each group was allowed to reproduce freely and each was provided food and water proportionately as their 
numbers increased. Once placed in the apparates with the top secured, the subjects were not disturbed except to remove any dead and to count any pups. The counting of pups was eruclal to the success of this experiment and was occomplished by pushing any adults in the nest out of the cubicle and barring the door with heavy wire inserted through the ceiling and floor. Once the pups were counted the wire was removed. The control group would not be allowed to multiply beyond the comfortable limits of their apparatus which was estimated to accommodate 197 mice. Should this figure have been exceeded, the extra subjects would have been removed. The experiment was terminated after six months and fourteen days. 
CHAPTER III

\section{RESULTS}

The results were not as anticipated-- there was no overpopulatIon In either experimental group, nor did the control group reach its earlier calculated asymptotic level. Each group controlled its population growth with respect to the density of its emvironment. Each experimental group began with active sexual behavior and within a month after arrival both groups began delivery of their first 1itters. WithIn no more than three days after delivery, each pup was subsequently killed and cannibalized by the adults. The methods by which the pups were exterminated varied with no one method paramount. Some were killed in the retrieval process. For a short period of time after the birth of each batch of pups, the females engaged in "baby swapping". Each female would endeavor to accumulate as many pups as possible into her nest. This activity could become quite frenetic and in the excitement the females often killed the pup they were trying to retrieve. Some pups were literally pulled apart by the females trying to retrieve it. Other pups died as a result of cannibalism. The cannibalism was performed by the entire population and not exclusively the female. Many pups were removed from the nest by members of the general population and eaten. Others were eaten in the nest area by either the female or some intruder. Finally, some pups died as a result of maternal neglect.

Figure 2 illustrates the survival rate for each group in the experiment. This rate is illustrated on a daily basis. The zero survi- 


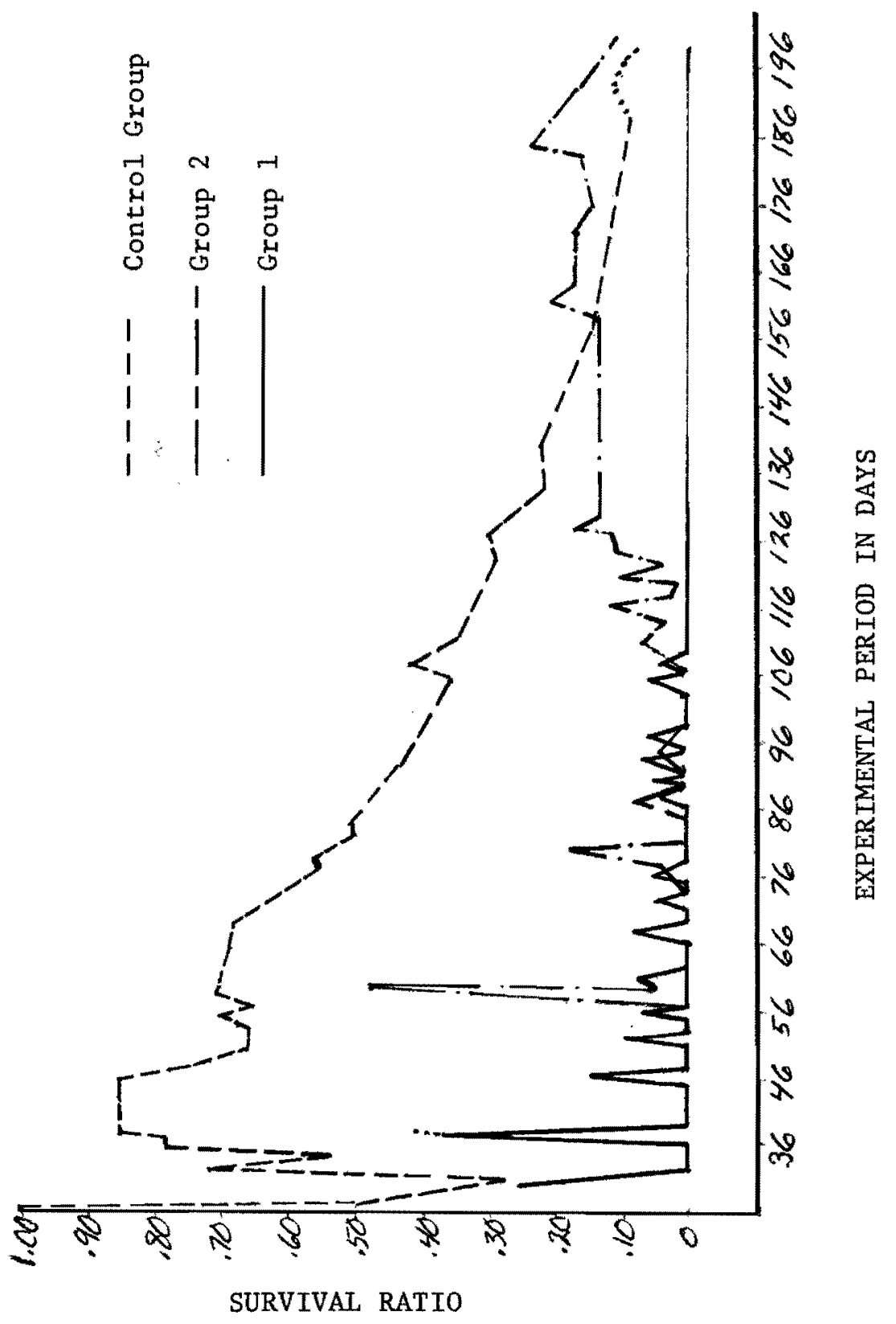

Figure 2. Mortality rate for the three population groups. 
val rate continued in experimental group one for seventy-seven days and a tulal of 130 pups, whereupor delivery ended for the rewainder of the experiment (ninety-ore days without a birth). Sexual activity within this group did not seem to diminish perceptively and there appeared to be pregnant females during the entire ninety-one day period. Since the gestation period for mice was only nineteen days (Gandelman, 1971), at least four more litters should have been born. IL would appear that intrauterine mortality existcd during this final ninety-one day period. This differs from Christian and Lemunyan (1958) for this effect did not appear in their groups until after overpopulation had occurred. By the ninety-fourth day of the experiment, twelve days before the final pup was born, the total population had reduced itself to twelve adults; eight females and four males remained. After this date, there were no more births or deaths among the adults.

Experimental group two followed much the same pattern as did experimental group one. For seventy-three days after its first births, this group delivered and exterminated 113 pups (see figure 2); and by the seventy-second day, it had reduced its total population to fourteen; ten females and four males. On the 108th day of the experiment, three months prior to the experiment's termination, experimental group two was artificially reduced in population to eight, seven females and one male, to see if this trend of a zero survival rate would change and at what density level this change might occur. The results of this artificial population reduction were dramatic. In the next litter after reduction, twenty-three pups were weaned out of a total of fifty-six births (forty-one percent survival). The total popula- 
tion of adults was now thirty-one. In the second litter after population reduction, twelve pups were weaned out of a total of forty births (thirty-percent surviva1). The total population was now forty-three. In the third and final 1itter, there were no survivors out of eightyfour births. Figure 3 illustrates the survival rate of experimental group two after its population was artificially reduced.

After an Initial fluctuation period, the survival rate of the control group stabilized at eighty-four percent and began to drop immediately until it reached ten percent at its lowest point, nine days prior to the termination of the experiment. On the 136th day, the control group reached its maximum density level of 116 adults; and from that point until the termination of the experiment, some fifty-one days later, there were no pups weaned. During that time period there were some 479 pups born. At the time the experiment was terminated, there was a total of thirty-five pups allve and it cannot be said with absolute certainty that all of these pups would have died; however on the 188 th day, the number of young was zero and in the following nine days some ninety pups were born of which these thirtyfive remained. The overall survival rate for the control group on the 188 th day reached its lowest point of 10.66 percent. These final nine days are represented in Figure 2 by a broken line. At the time of termination, there was a total of 112 adults and there had been a total of 1056 births within this population. An interesting point emerges from a comparison of the density level of experimental group one and the control group at its highest adult population level of 116 . The 1ivable area in cubic inches for group one was 2237.50 and for the control group was $22,443.375$. When calculated for each mouse the 


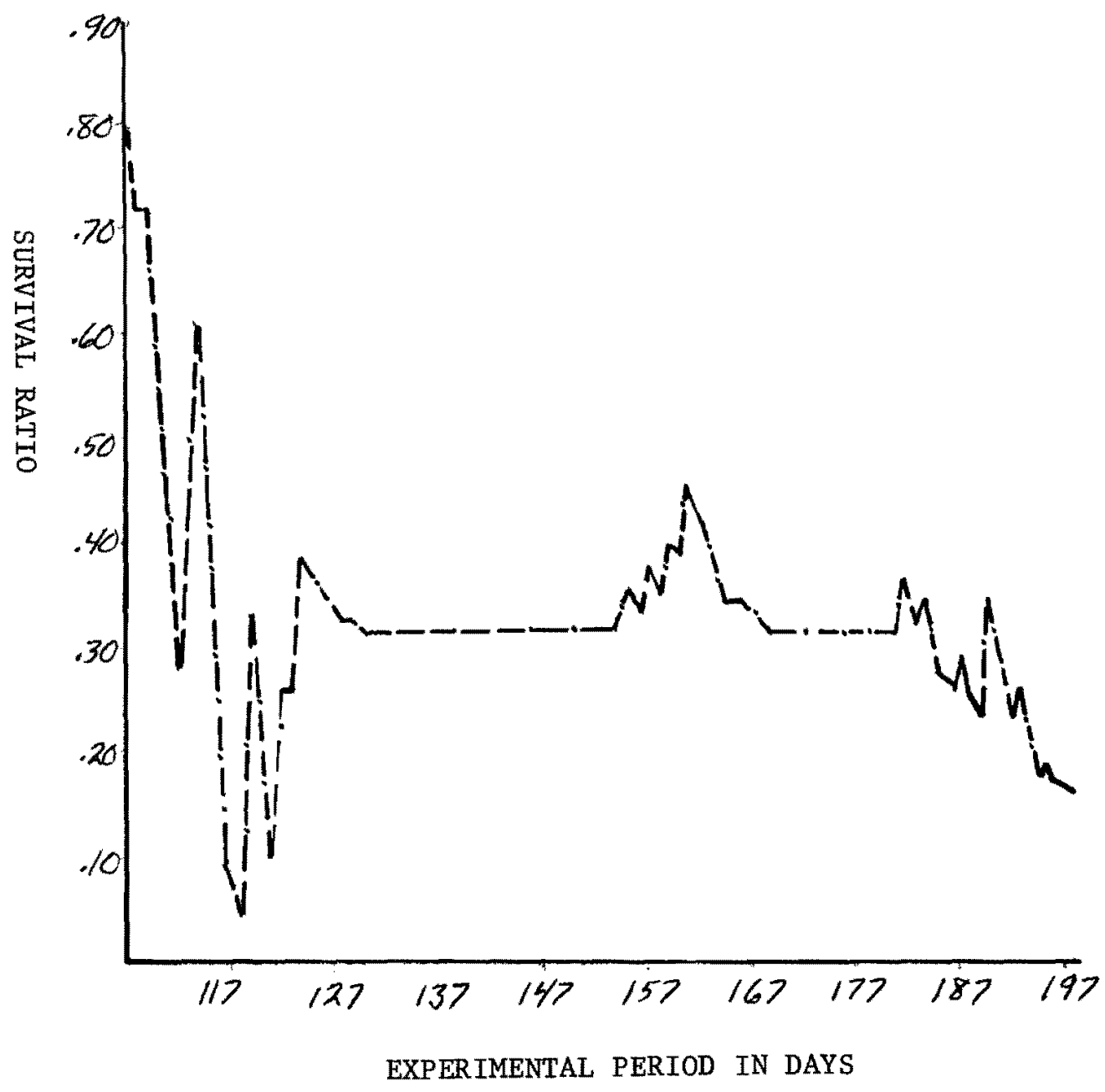

Figure 3. Survival rate for experimental group two after artificial population reduction. 
results are 186.46 cubic inches/mouse for group one and 193.48 cubic inches/mouse for the control group. At its widest range there was only a 13.92 cubic inch/mouse difference between group one and the control group. It would appear from these results that the two populations both stabilized at nearly the same density level; one by reducIng its adult population and exterminating its young; the other by controlling the survival rate of its young.

The other five variables were analyzed even though overpopulation did not occur. With the lack of overpopulation there was no observed decrease in grooming activity for any of the three groups. At no time during the experiment were any unkempt mice seen. There was no increase in homosexual behavior in any group. In fact, only upon one occasion was a homosexual act observed and it occurred in the control group.

Nest building for individual females could not be determined as earlier proposed. Females did not construct separate nests, instead they combined their efforts and built communal nests, usually shared by two or three females in the experimental groups and from two to eight females in the control group. It was also noted that non-pregnant females and even males constructed nests, and at times pregnant females would comandeer these already constructed nests. For the entire experiment there was a mean of $3.4,2.3$, and 5.3 nests for the control group, group one, and group two respectively. The only noticeable change in this variable occurred in the control group: at first only bowl type nests were observed, but as the survival rate began to decline more and more platform nests were constructed until at 
a twenty-nine percent survival level no more bowl type nests were observed. Southwick (1955) noted a sharp decline in survival when the type of nest construction changed. There was no change in nest type observed in the experimental groups. Both constructed only bowl type nests.

The results for the retrieval of the young are illustrated in Figure 4. For each group there were periods of time in which no pups existed; rather than represent this time period in Figure 4 the graph for each group was collapsed, and each illustration is for the time period in which there were pups for possible retrieval. The abscissa represents the total number of days there were pups in each group and the ordinate is the ratio of retrievals per group. For each experimental group the highest number of retrievals came at or near the time of birth and then began to drop off immediately until, at the time of weaning, the pups were too large to retrieve and the ratio fell to zero. In Figure 4 the births and weaning periods are noted for each experimental group. This same phenomenon does not seem to hold for the control group: there seems to be no relationship between the time of birth and the increase in retrieving. In comparing the two experimental groups with the control group, it was noted that at the time of the births the interactions between adults and pups as measured by the retrieval ratio was considerably higher for the experimental groups than for the control group. The frequency of interaction (retrieva1) began to increase in the control group as the population neared its crucial density level.

The results of the fighting variable are 1llustrated in Figure 


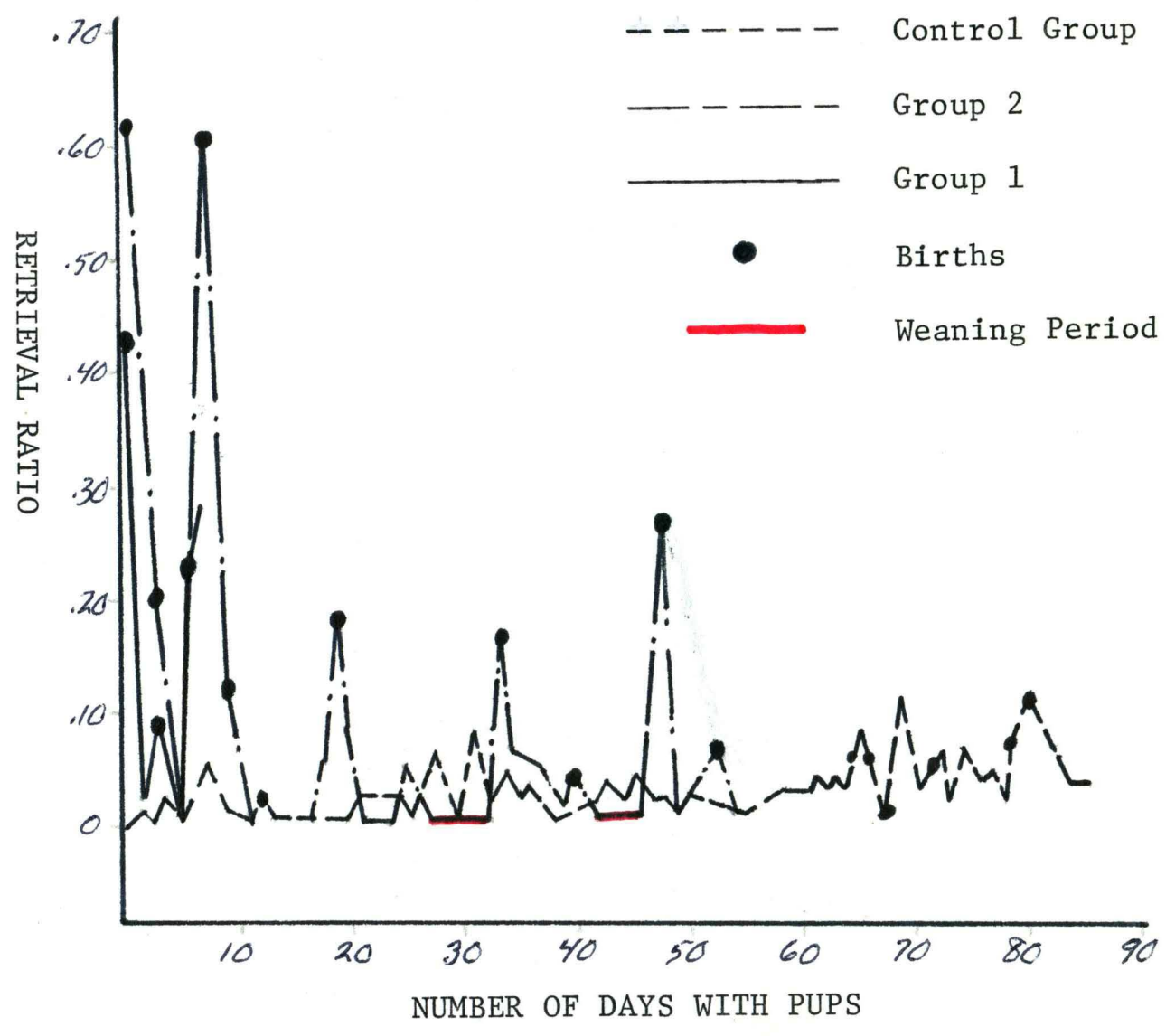

Figure 4. Frequency in retrieval of the young for all three groups. 
5. For the first fifteen weeks there appears to be no particular trends being established. Each group begins with an initial low period soon followed by a rapid increase in fighting. From this point (about the sixth week), the groups begin to vary in their fighting behavior with no particular predictable pattern. From the fifteenth week until the termination of the experiment, group one and the control group continue the same fighting behavior that they had established in the first fifteen weeks; however, group two changed. At the fifteenth week experimental group two's population was artificially reduced and within a week the frequency of fighting had been reduced by more than one-half. By the second week after reduction, fighting had stopped and was nonexistent for four weeks. When the first pups were weaned during the twenty-first week, fighting promptly rose and at the second weaning during the twenty-fifth week fighting reached its highest point for the entire experiment. A11 notable points are illustrated in Figure 5. In the control group an interesting aside was noted: when the fighting began to increase many males would escape by hanging from the wire screen top of the apparatus. As the population began to grow and the hiding places became more limited, this peculiar behavior increased. Many animals would sleep while hanging in this position. There were occasions when as many as twenty males would be seen hanging from the top. In the entire experiment no female was ever observed engaged in this behavior nor was this behavior ever evidenced in either experimental group. Another variable which was not tested but was noted because of curiosity and the fact that Calhoun (1962) found it to be important 

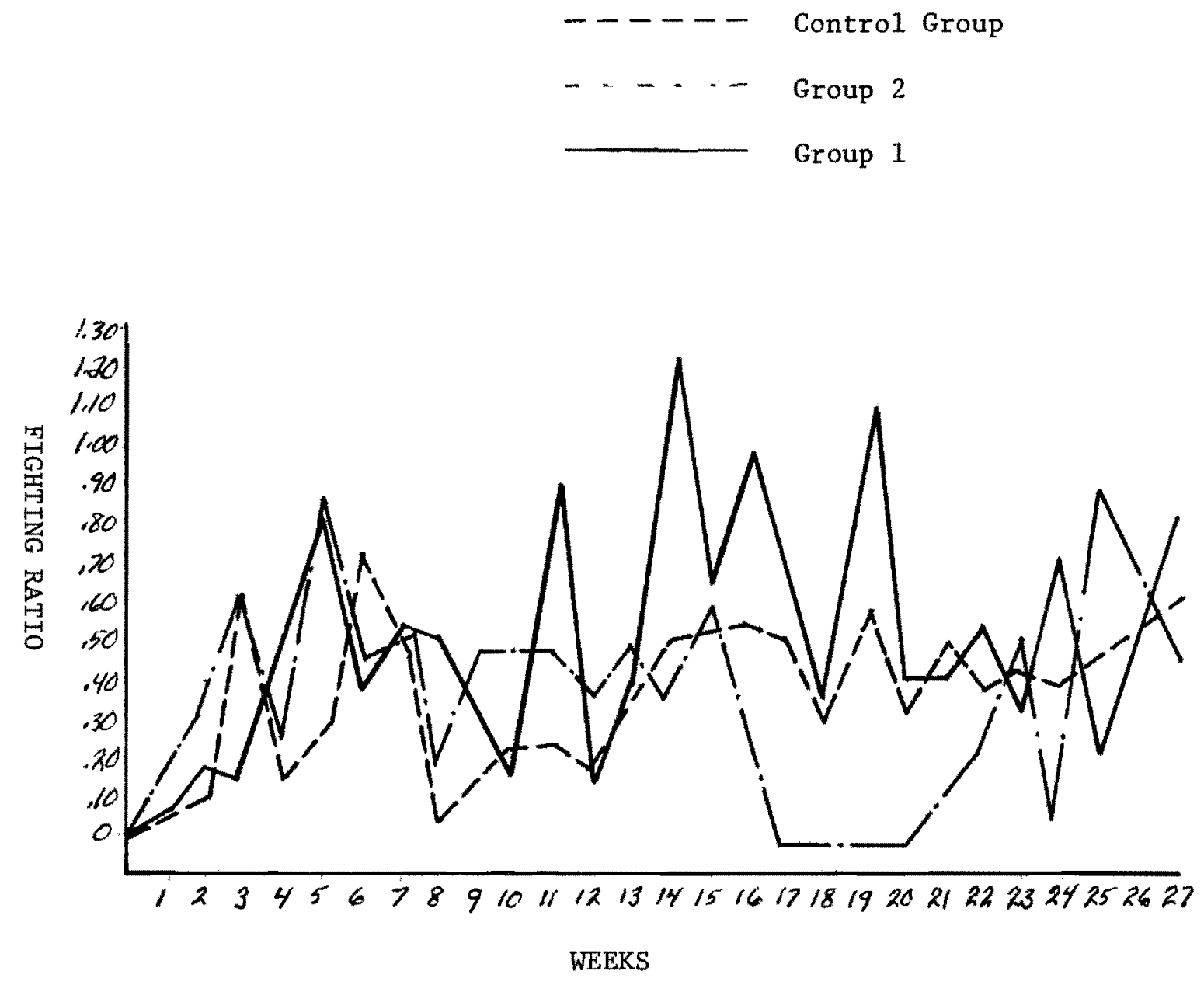

Figure 5. Fighting behavior for all groups. 
was the defining of territories and collecting of harems. Neither of these characteristic behaviors were observed in either experimental group; however early in its population growth, the control group set up territories. There seemed to be no apparent harems just territories. After an initial adaptive period most of the mice in the control group settled down in the cubicles nearest the food and water. In appearance it was much like Calhoun's "behavioral sink". At this time there was one group of males who were driven out of this living area and foeced to live at the far end of the apparatus. This group varied in size from two to eight males. Each time one of these animals left his cubicle to acquire food or water he was promptly attacked and driven back to his cubicle. The attacks came from both males and females and, at a later time, even juveniles. There never appeared to be any females in this group, however females would enter the cubicle to engage in mating activities. As the density level began to increase within this group, the territorialism began to break down as did the "behavioral sink". Finally there were no more territories, nor was there a "behavioral sink" as described by Calhoun (1962).

Another curious behavior manifested itself in all three groups shortly after the birth of the first 1itter. For some reason the population would periodically move the entire nest, paper and pups, to a new cubicle. For example, in one three week period the control group moved their nest forty-three times. Often there was more than one nest constructed; therefore the movement figure includes any building of a new nest and movement of pups from an already constructed nest to it and movement of the entire nest. This behavior tapered off and 
soon ended as the population grew in the control group. This behavior occurred sporadically in experimental group two and terminated on the 108th day in group one. Other than the behaviors described, no other variables were observed or recorded. 
CHAPTER IV

\section{DISCUSSION}

The most important single factor in this experiment was the fact that experimental group one and the control group never overpopulated, and that experimental group two never weaned a pup until artificially reduced in number. No other experiment reviewed had this phenomenon occur. In all other research, the populations first overpopulated then reduced their numbers. This experiment suggests an inborn population control mechanism based upon the density available per mouse; and as this crucial density level is approached, the population will stop its own growth. The term crucial is here defined as that particular point or range which, if exceeded, results in overpopulation. This crucial density level is variable and determined by each population independently. From the initial reaction of groups one and two, both reduced their adult population, it would appear that a population can also reduce its adult members to this "inborn" density level. The crucial density level which was determined by noting the control group at its highest adult level $(\mathrm{N}=116)$ and experimental group one $(\mathrm{N}=12)$, at its constant level after initial population reduction, was calculated as $189.97^{\ddagger} 3.51$ cubic inches/mouse. If the calculation were made using the control group at its lowest adult level $(N=112)$, the resultant crucial density level is $193.42 \pm 6.96$ cubic inches/mouse. There is only a \pm 3.45 cubic inch difference per mouse between these two crucial density levels depending upon how they are calculated. From the examination of these results, one could hypothesize that when 
a given population of mice neared this calculated crucial density range $\left(189.97 \pm 3.51 \mathrm{in}^{3}\right.$ to $\left.193.42 \pm 6.96 \mathrm{in}^{3}\right)$ it would begin to control its growth to stay within this range, and that any population placed in an environment wich a higher crucial density range would reduce itself to meet this level. The results of this experiment substantiate such a hypothesis.

Experimental group two, after artificial population reduction, exceeded this crucial density level; however this increase can be accounted for under the innate population control hypothesized earlier. When the experiment began, group two followed the same trend as did group one in that it quickly reduced its adult population from sixteen to fourteen and did not allow any pups to survive. On the 108th day, this group was artificially reduced to eight. At the time of reduction its density level was 159.82 cubic inches/mouse; therefore we cannot state with any accuracy that this group would have reduced itself any further. However one cannot say that it would not have continued as did group one, eventually reaching the calculated crucial density level. At group two's reduced level of eight, the density level per mouse was 279.69 cubic inches. After reduction this group weaned twenty-three mice in their first litter, twelve mice in their second litter, and non in their final litter (note Figure 3). The high survival rate for its first litter, forty-one percent, can be accounted for: until the pups are weaned and start interacting with the general population, they do not significantly affect the density level for the group. When these twenty-three pups were weaned, the population density was reduced to 72.18 cublc inches/mouse. From the 
earlier hypothesis one would assume that the survival rate for the second litter would be zero, however the survival rate was thirty percent. The density level after the second litter was 59.03 cubic Inches/mouse.

What seems to have occurred is a time lag between the number of births and the effects of those births on the population controls; the population was soon affected as demonstrated by the zero survival rate for the third litter. This group did terminate its survival rate and, although it is only conjecture, it is possible that given more time experimental group two would have continued a zero survival rate and reduced its adult population to the crucial density level. This group would not have exceeded the crucial density level if it had gradually approached it. The evidence for this statement is based upon the population growth of the control group. This group never exceeded the crucial density level because it had time to alter its growth before reaching this 1imit. Group two was below the crucial level before weaning the pups and upon weaning exceeded this level. Before the effects of the higher population density could be a factor, group two had produced its second litter. It was evident the effects of a high density level had begun to make its presence known because the survival rate for this second litter was only thirty percent. The full effect was felt by the third litter for none of the pups survived. It would appear that the effects of population growth on the inborn population control factor are directly tied to time. If the population has the time to approach the crucial density level gradually, it will not overpopulate; if, however, the crucial density level is met 
with little or no approach time, it will be exceeded and the population will be overpopulated. If overpopulation should occur, the group will then begin to return to its inborn crucial density level by reducing the adult population and reducing their survival of new born pups to zero.

The results of this experiment have not been found in any other study on overpopulation. What is it about these groups which makes them uniquely different from all other populations studied? At this point the question seems to defy answer. Populations, both experimental and natural, seem to control their growth; however the variables that affect this control do not begin until after overpopulation has occurred (Calhoun, 1962; D'Aulaire and D'Aulaire, 1970). Possibly the difference in results is due to a procedural difference between this experiment and all others reviewed. Some experimenters like Calhoun (1949, 1962) and Morrison and Thatcher (1969) have used rats in their studies on overpopulation, and their findings might differ from this experiment's due to a species difference. Since one cannot generalize from the results of animal studies to a prediction of human behavior, one might also assume that he cannot generalize from the results of studies using rats to those using mice. Also any studies such as Pear1's (1932) which used a different animal (fruit flies) cannot be compared to mice for the same reason. Another group that can be eliminated in this quest for universality are those experimenters who artificially overpopulated their groups and did not allow natural overpopulation (Christian \& Lemunyan, 1958; Thiessen, 1964). One cannot assume that the behavioral changes that result from arti- 
ficial overpopulation would be the same as those for natural overpopulation. Even those experimenters who used mice and allowed natural overpopulation might argue that these results are not equivalent because we used a different strain of mice (Brown, 1953; Southwick, 1955). The one study which cannot be eliminated for any of these reasons is the pilot study conducted prior to this experiment. In that study the same strain of mice were used and the procedures for conducting the experiment were identical. However the result was overpopulation. Essentially the only difference between the pilot study and this experiment was the flooring in the pilot study apparatus. The flooring in the pilot study apparatus was solid wood covered with litter material, while the apparatuses of this experiment were florred with quarter inch hardware cloth. What effect this difference in apparatus might have cannot be determined without further research. It would seem that none of these differences can adequately explain why no overpopulation occurred in this experiment but did in a11 others. Al1 other experiments-- regardless of species of animal used, apparatus, or general procedure-- got overpopulated.

Without further research it would seem highly presumptuous to postulate a cause for the paradoxical situation thus described; however if one is allowed to speculate, a plausible solution is possible. Assume that a population is more than just a collection of individuals. A population has inherent characteristics of its own with its own personality and idiosyncrasies. If a population could be considered a single entity with one personality, the same psychological tenets could apply to that population as to the individual. The concept of 
Individual difference, applied to the population would become this: because one population overpopulates does not mean that all populations wi11 overpopulate.

Because of the results of overpopulation studies like Calhoun's (1962), many contemporary writers have generalized from these results to the possible outcome of human population growth. Based upon these studies, Ardrey (1970) has postulated that much, if not al1, of our violence in the world is directly attributable to overcrowding which is a byproduct of overpopulation. He feels the overcrowded society may be headed for chaos or dictatorship. Ehrlich (1968) has hypothesized the annihilation of the human race if it does not stop its rapid population growth. Morris (1967) concluded from the results of other studies that a "catastrophic upheaval" must result from overpopulation but that if some "controlled anti-reproductive device" could be introduced at the first signs of overpopulation, chaos could be averted. From the results of this experiment it would appear that this is exactly what occurred, each group employed anti-reproductive devices and avoided inevitable overpopulation and chaos. A11 of these authors have risked an obvious violation, that of generalizing from the behavior of non-human species to humans; this generalization cannot be made with any degree of certainty.

Besides the growth of the population, the density level also affected other variables tested. Without overpopulation, grooming and heterosexual behavior were unaffected and this was as one might. expect. Nest building was not directly affected by density, and as earlier noted the females combined efforts and constructed communal 
nests. Indirectly the physical size and shape of the apparatus did seem to affect nest building and to a certain degree the retrieval of the young. The cubicles in the experimental groups were smaller than those in the control group which allowed fewer females to inhabit them. No more than two pregnant females were ever observed to occupy a single nest in the experimental groups, whereas up to eight pregnant females were observed occupying a single nest in the control group. Because of this inequality in nest dispersal, there was less opportunity or need for retrieva1 of the young in the control group. With nearly all the mothers and their pups confined to one nest, there was less need to move the pups; and 1ittle or no "baby swapping" occurred. The greater number of nests in the experimental groups allowed more "baby swapping" to occur where the pups were available. This aval1ability is reflected in the greater retrieval ratio exhibited by both experimental groups (see Figure 4).

Another interesting phenomenon occurred with the retrieval variable. In each experimental group the retrieval process increased rapidly with each birth and then dropped off equally as fast. This pattern of retrieval did not occur in the control group; in this group there was little correlation between the retrieval frequency and time of birth. The central factor determining the cause of this difference In behavior seemed to be the age of the young. The pups did not survive long enough in the experimental groups for the adults to accustom themselves to their presence; whereas in the control group there were always pups alive so the birth of new pups did not cause frenetic "baby swapping" as it did in the experimental groups. 
The final variable directly influenced by the density level was fighting. Until the fifteenth week there was no way of determing if the density level was having any effect on the fighting behavior of the groups. No group had established any pattern in its fighting behavior. At the fifteenth week experimental group two was artificlally reduced in number and its fighting behavior almost immediately dropped to zero and remained there until the first population addition some six weeks later. From this result it would appear that aggression in the form of fighting is directly tied to the density level. This would seem to support Ardrey's (1970) conclusions with regard to aggression and overcrowding. The interesting point noted with this variable is that fighting is directly correlated with population density at all levels of population growth. Overpopulation does not have to occur for there to be a substantial increase in fighting frequency. Ardrey may be correct when he attributes aggression to overcrowding and not directly to overpopulation as does Calhoun (1962). At this point a distinction should be made between overcrowding and overpopulation for they are not synonymous terms. Overcrowding is the substantial increase in the density within a section of a particular environment, while the entire environment is not particularly affected. For example, Australia is not considered a high density environment while Sidney is a highly dense area within that environment. Overpopulation occurs where the entire environment is densely populated. These two terms are often used interchangeably when, it is felt, there is a distinct difference between them. 
Future research

It has been demonstrated in this experiment that not all populations need overpopulate. Unfortunately because no other experimenter has had similar results, more research is needed to substantiate these findings. First, another experiment should be done in an effort to replicate the findings of this experiment. If these results are replicated, one should then bagin to compare these findings to those of other researchers like Calhoun (1962) in an effort to find that variable or variables which might be involved in producing the differIng results. One would need to test the differences of species, apparatus, and procedures to evaluate what affect each had on population growth. If the results are not replicated, the effort must be focused on why they were not and on the variables that might be involved. No variable regardless of seeming insignificance should escape testing. Such variables as the lighting schedule, heat, ventilation, nesting material, apparatus design, and frequency of personal encounter might all play a significant role in the growth of a population. Incorporated into any future research on population growth must be the physiological affects of density. Gandelman (1971) may have given an important clue with his implication that the lateral hypothalamus may be directly involved in maternal care. If this area of the brain is affected by fighting, this could be the determining factor in the differing population growths observed. This experiment implies that, to date, not all the influences upon population growth are known nor can It be assumed that a population if allowed to grow will overpopulate. 


\section{REFERENCES}

Archer, J. Effects of aggressive behavior on the adrenal cortex in male laboratory mice. Journal of Mammalogy, 1970, vol. 51, no. $2,327-332$.

Ardrey, R. The Social Contract (at press) cited in the violent way. Iffe, 1970, vol.69, no.11, 56B-68.

Beeman, E. A., \& Alee, W. C. Some effects of thiamin on the winning of social contacts in mice. Physiological zoology, 1945, 18 , 195-221.

Bronson, P. H., E Eleftheriou, B. E. Adrenal responses to crowding in peromysous and $\mathrm{c} 57 \mathrm{BL} / 10 \mathrm{j}$ mice. Physiological zoology, 1963, $36,161-166$.

Brown, R. Z. Social behavior, reproduction, and population changes in the house mouse (Mus musculus L.). Ecological Monographs, $1953,23,217-240$.

Calhoun, J. B. A method of self-control of population growth among manmals 1iving in the wild. Science, $1949,109,333-335$.

Calhoun, J. B. The study of wild animals under controlled conditions. Annals of the New York Acadeny of Science, 1950, 51, 1113-1122.

Salhoun, J. B. The social aspects of population dynamics. Journal of Mammalogy, 1952, vo1.33, no.2, 139-159.

Calhoun, J. B. Population density and social pathology. Scientific American, 1962, 206(2), 139-148.

Christian, J. J. Adrenal and reproductive responses to population size in mice from freely growing populations. Ecology, 1956, $37,258-273$.

Christian, J. J. Phenomena associated with population density. Proceedings of the National Academy of Science, 1961, 47 , 428-449.

Christian, J. J., \& Lemunyan, C. D. Adverse effects of crowding on reproduction and lactation of mice and two generations of their progeny. Endocrinology, 1958, 63, 517-529.

Crowcroft, P., \& Rowe, F. P. The growth of confined colonies of wild housemouse (Mus musculus L.): The effect of dispersal on fecundity. Proceedings of the Royal Zoological Society of London, 1958, 131, 357-365. 
D'Aulaire, 0., \& D'Aulaire, E. The lesson of the lemmings, Vilkkosanomat, 1970, cited by Reader's Digest, 1970, vo1.97, no.580, 167-172.

Davis, D. E. The characteristics of rat populations. Quarterly Review of Biology, 1953, 28, 373-401.

Davitz, J. R., \& Mason, D. J. Socially facilitated reduction of a fear response in rats. Journal of Comparitive and Physiologica1 Psychology, 1955, 48, 149-151.

Deevey Jr., E. S. The human population. Scientific American, 1960, vo1.203, no. 3, 194-204.

Ehrlich, P. R. The Population Bomb. Ballantine books, inc., 1968.

Evans, F. C. A population study of house mice (Mus musculus) following a period of local abundance. Journal of Mammalogy, $1949,30,351-363$.

Gandelman, R. et al Olfactory bulb removal eliminates maternal behavior in the mouse. Science, 1971, vol.171, no.3967, 210.

Hays, W. L. Statistics. New York: Holt, Rinehart and Winston, 1963, 598-601.

Kalela, 0. Regulation of reproduction rate in sub-arctic populations of the vole. Clethrion Rufocanus (Sund). Annals of the Academy of Science Fennical, ser. A, 4, Biologica, no.34, 1957. cited In Christian, J. J. Phenomena associated with population density. Proceedings of the National Academy of Science, 1961, 47, 428449 .

Iidde11, H. Some specific factors that modify tolerance for environmental stress. Res. Pul1. Ass. Nerv. Ment. Dis., 1950, 29, 155-171. cited in Davitz, J. R., \& Mason, D. J. Socially facilitated reduction of a fear response in rats. Journal of Comparitive and Physiological Psychology, 1955, 48, 149-151.

MacLagan, D.S., \& Dunn, E. The experimental analysis of the growth of an insect population. Proceedings of the Royal Society of Edinburgh, 1934-35, 55, 126-139. (Abstract)

Masserman, J. H. Behavior and Neurosis. Chicago: University of Chicago press, 1943.

Morris, D. The Naked Ape. New York: De11 publishing co., inc., 1967, 82-84. 
Morrison, B. J., \& Thatcher, K. Overpopulation effects on social reduction of emotionality in the albino rat. Journal of Comparative and Physiological Psychology, 1969, vol. 69, no.4, 658-662.

Pearl, R. The growth of populations. Quarterly Review of Biology, $1927,2,532-548$.

Pearl, R. The influence of density of population upon egg production In Drosophila Melanogaster. Journal of Experimental Zoology, $1932,63,57-84$.

Pearl, R., \& Reed, L. J. The logistic curve and the census count of 1930. Science, 1930, 72, 399-401.

Retzlaff, E. G. Studies in population physiology with the albino mouse. Biological Generalis, 1938, 14, 238-265. cited in Christian, J. J. Adrenal and reproductive responses to population size in mice from freely growing populations. Ecology, $1956,37,258-273$.

Scott, J. P., \& Fredericson, E. The cause of fighting in mice and rats. Physiological Zoology, 1951, 24, 273-309.

Southwick, C. H. The population dynamics of confined house mice supplied with unlimited food. Ecology, 1955, 36, 212-225.

Southwick, C. H. Regulatory mechanisms of house mouse populations: Social behavior affecting litter survival. Ecology, 1955, $36,627-634$.

Strecker, R. L. Populations of house mice. Scientific American, $1955,193,92-100$.

Strecker, R. L., \& Emlen, J. T. Jr. Regulatory mechanisms in housemouse populations: The effect of limited food supply on a confined population. Ecology, 1953, 34, 375-385.

Thiessen, D. D. Population density, mouse genotype, and endocrine function in behavior. Journal of Comparitive and Physiological Psychology, 1964, vol.57, no.3, 412-416.

Woolston, H. Raymond Pear1: The biology of population growth. American Journal of Sociology, 1929, 35, 403-410. 